\title{
SURFACE BEHAVIOR OF AISI 4140 MODIFIED WITH THE PULSED-PLASMA TECHNIQUE
}

\author{
LASTNOSTI POVRŠINE AISI 4140, SPREMENJENE S TEHNIKO \\ PULZIRAJOČE PLAZME
}

\author{
Yıldız Yaralı Özbek, Mehmet Durman \\ Sakarya University, Engineering Faculty, Department of Metallurgical and Metarials Engineering, Esentepe Campus, 54187 Sakarya, Turkey \\ yyarali@sakarya.edu.tr \\ Prejem rokopisa - received: 2013-10-02; sprejem za objavo - accepted for publication: 2014-07-17
}

doi:10.17222/mit.2013.219

\begin{abstract}
In this study, the microstructure and surface properties of a low-alloy steel (AISI 4140) treated with pulsed plasma were investigated. Three different plasma-gun nozzle distances of $(60,70$ and 80$) \mathrm{mm}$ and one battery capacity were chosen for a surface modification. The modified surface layers were examined using a light microscope and X-ray analyses were carried out for all the samples. The X-ray diffraction confirmed a development of new phases after the surface treatment. The samples were subjected to micro-hardness measurements and it was found that the hardness values of the modified surfaces were four times higher than those of the untreated samples. The samples were immersed into liquid nitrogen and then broken in a Charpy machine. The fractured surfaces were exposed to SEM and EDS analyses. At the end of the study, thin grains originating from the consumable electrode were detected. After the pulsed-plasma treatment, new structures were obtained.

Keywords: pulsed plasma, fracture, consumable electrode, modification
\end{abstract}

V tej študiji so bile preiskovane mikrostruktura in lastnosti površine malolegiranega jekla (AISI 4140) po obdelavi s pulzirajočo plazmo. Za spremembo površine so bile izbrane tri različne razdalje plazemske šobe od površine: $60 \mathrm{~mm}, 70 \mathrm{~mm}$ in $80 \mathrm{~mm}$, in kapaciteta ene baterije. Spremenjene površinske plasti so bile preiskovane s svetlobnim mikroskopom in izvršene so bile rentgenske analize. Rentgenska difrakcija je potrdila nastanek novih faz po obdelavi površine. Na vzorcih so bile izvršene meritve mikrotrdote in ugotovljeno je bilo, da je trdota spremenjene površine štirikrat večja od tiste pri neobdelanih vzorcih. Le-ti so bili potopljeni v tekoči dušik in nato prelomljeni na napravi Charpy. Površina preloma je bila analizirana s SEM in EDS. Odkrita so bila drobna zrna, ki izvirajo iz elektrode. Po obdelavi s pulzirajočo plazmo je nastala nova mikrostruktura.

Ključne besede: pulzirajoča plazma, prelom, porabljiva elektroda, sprememba

\section{INTRODUCTION}

High-intensity pulse or plasma irradiation has recently gained a growing interest as a potential tool in surface engineering. As in the cases of a laser or electron beam, ions from a pulsed beam rapidly heat the surface of the irradiated material. The surface remains at a high temperature (up to the melting point or higher) for a period in the nanosecond to microsecond range, and then rapidly cools through conduction into the bulk at the rates of the order of $10^{7}-10^{10} \mathrm{~K} / \mathrm{s}$. Obviously, the details of the heat evolution in a substrate depend on its thermal properties and dimensions as well as on the beam parameters. Heat-induced processes result in several nonequilibrium phenomena such as the mixing of metallic overlayers on various (even hardly miscible) substrates, the formation of metastable crystalline alloys and so on. Besides purely thermal effects, ion or plasma beams are used as well. It is also possible, under appropriate conditions, to modify the surface properties of solids via thermal effects in conjunction with the mass transport. ${ }^{1-3}$

The pulsed-plasma process is used to improve the surface properties of the workpieces of tool steels. ${ }^{1-6}$ The pulsed-plasma system has high rates of heating and cooling. These lead to the formation of a nano/microcry- stalline structure, a high dislocation density and a growth of the concentration of the alloying elements and, thus, an intensification of the diffusion mechanisms. ${ }^{3-5}$

In general, a modified surface consists of a compound layer (the white layer) that is a few micrometers deep. In the diffusion zone the nitrogen atoms can be interstitially dissolved or precipitated as iron nitrides, tungsten and/or tungsten alloys from the consumable electrode used. As a result, metastable states may appear in the surface layers, which are the origin of the improved physical, chemical and mechanical properties unattainable with the conventional surface-treatment techniques. ${ }^{5}$

The process parameters have significant effects in determining the final structure and mechanical properties of the surfaces. Among these parameters the controlling gas diffusion through the nozzle distance and the number of pulses, and the plasma composition are the most important ones. A proper combination of these parameters would provide the best surface properties and set out the duration of the process time as an important economic factor. ${ }^{1}$ The pulsed plasma is the most advantageous one; its process time is very short (1 $\mathrm{min})$, it is more economical and it can produce superior mechanical properties. 
The aim of this study is to improve the material performance and functional properties of the surface of a commonly used steel without long and expensive heattreatment operations. AISI 4140 was used in this study. The AISI 4140 steel is the most common type of steel dealt with in the studies discussing different methods. Different parameters of pulsed plasma were tried on the samples.

\section{EXPERIMENTAL PROCEDURE}

The standard, medium-carbon, low-alloy AISI 4140 steel was used in the study and the chemical composition of the steel is given in Table 1. The samples were exposed to the pulsed-plasma-modification technique. A schematic illustration of the pulsed-plasma technique used for the modification of the samples is shown in Figure 1. The parameters of pulsed plasma are given in Table 2.

Table 1: Chemical composition of the AISI 4140 steel used in the study in mass fractions, $w / \%$

Tabela 1: Kemijska sestava jekla AISI 4140, uporabljenega za preizkuse v masnih deležih, w/\%

\begin{tabular}{|c|c|c|c|c|c|c|c|}
\hline $\begin{array}{l}\text { AISI } \\
4140\end{array}$ & $\mathrm{C}$ & $\mathrm{Si}$ & $\mathrm{Mn}$ & $\mathrm{P}$ & $\mathrm{S}$ & $\mathrm{Cr}$ & $\mathrm{Mo}$ \\
\hline$w / \%$ & 0.40 & 0.30 & 0.70 & 0.035 & 0.035 & 0.98 & 0.27 \\
\hline
\end{tabular}

Table 2: Parameters of the pulsed-plasma process

Tabela 2: Parametri postopka pulzirajoče plazme

\begin{tabular}{|c|c|c|c|c|}
\hline No. & $\begin{array}{c}\text { Nozzle } \\
\text { distance } \mathrm{mm}\end{array}$ & $\begin{array}{c}\text { Number of } \\
\text { pulses }\end{array}$ & $\begin{array}{c}\text { Battery } \\
\text { capacity, } \mu \mathrm{F}\end{array}$ & $\begin{array}{c}\text { Consumable } \\
\text { electrode, } \mathrm{W}\end{array}$ \\
\hline 1 & 70 & 15 & 800 & Tungsten \\
\hline 2 & 70 & 10 & 800 & Tungsten \\
\hline 3 & 70 & 5 & 800 & Tungsten \\
\hline 4 & 80 & 15 & 800 & Tungsten \\
\hline 5 & 80 & 10 & 800 & Tungsten \\
\hline 6 & 80 & 5 & 800 & Tungsten \\
\hline 7 & 60 & 15 & 800 & Tungsten \\
\hline 8 & 60 & 10 & 800 & Tungsten \\
\hline 9 & 60 & 5 & 800 & Tungsten \\
\hline
\end{tabular}

The specimens used in the pulsed-plasma experiments were cut from the center of the modified surfaces with a cutting machine (Discotom-6) and then put in Bakelite. After that, they were grinded with the emery paper and polished. The samples were studied with a light microscope using different magnifications. The hardness values of the specimens were measured with a Future-Tech test apparatus for $15 \mathrm{~s}$ under a load $5 \mathrm{~g}$. The phase compositions of the modified surfaces were investigated with X-ray diffractometry (XRD) using a Rigaku diffractometer employing monochromatic $\mathrm{Cu}-\mathrm{K} \alpha$ radiation. After the pulsed-plasma process, the notched specimens were immersed into liquid nitrogen for two minutes and then they were cracked with a Charpy test machine from the notched regions. The fractured regions were analyses with a scanning electron microscope

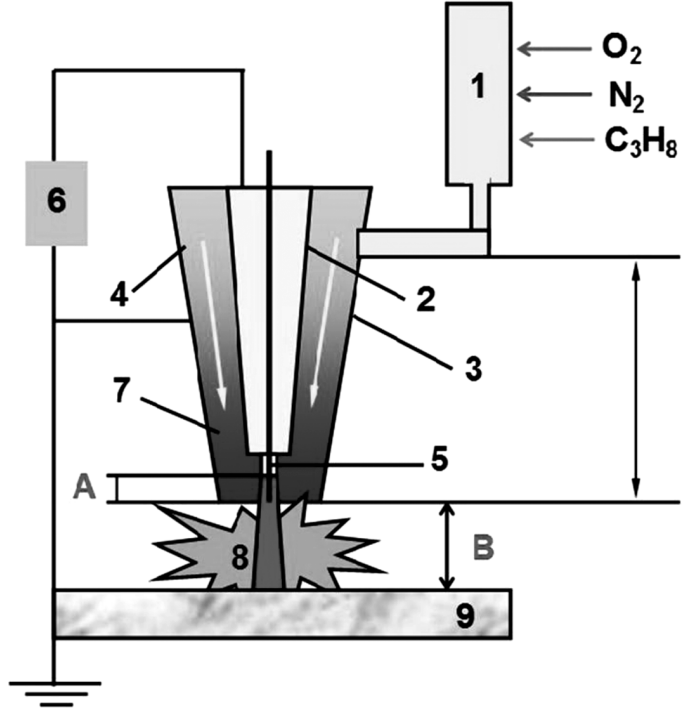

Figure 1: Schematic presentation of the pulsed-plasma modification system: 1-detonation chamber, 2-central electrode, anode, 3-conical electrode, cathode, 4-interelectrode gap, 5-consumable electrode, 6-power supply, 7-gap between the electrodes, 8-pulsed plasma forming, 9-work surface

Slika 1: Shematski prikaz sistema s pulzirajočo plazmo: 1-detonacijska komora, 2-centralna elektroda anoda, 3-konična elektroda katoda, 4-vrzel med elektrodama, 5-porabljiva elektroda, 6-izvir energije, 7-vrzel med elektrodama, 8-nastanek pulzirajoče plazme, 9delovna površina

JEOL 6600 (SEM) and an energy dispersive spectrometer (EDS).

\section{RESULTS AND DISCUSSION}

In Figure 2, a light microstructure of Sample 4 is shown. It was obvious from the microstructural examination that the modified layer and the substrate could be easily seen due to the light contrast. A white layer was formed on the surface layer.

A homogeneous and ordered layer was obtained by increasing the pulse number as seen in the light

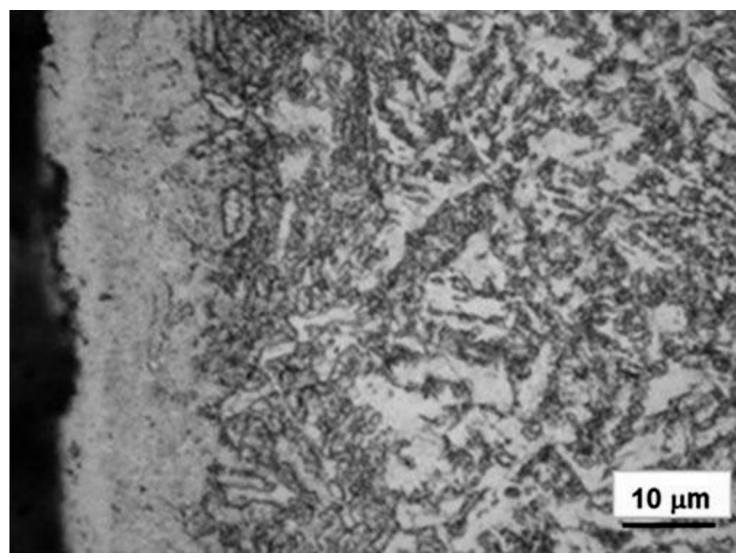

Figure 2: Microphotograph of the cross-section of Sample 4 modified with pulsed plasma

Slika 2: Mikrostruktura prereza vzorca 4, obdelanega s pulzirajočo plazmo 

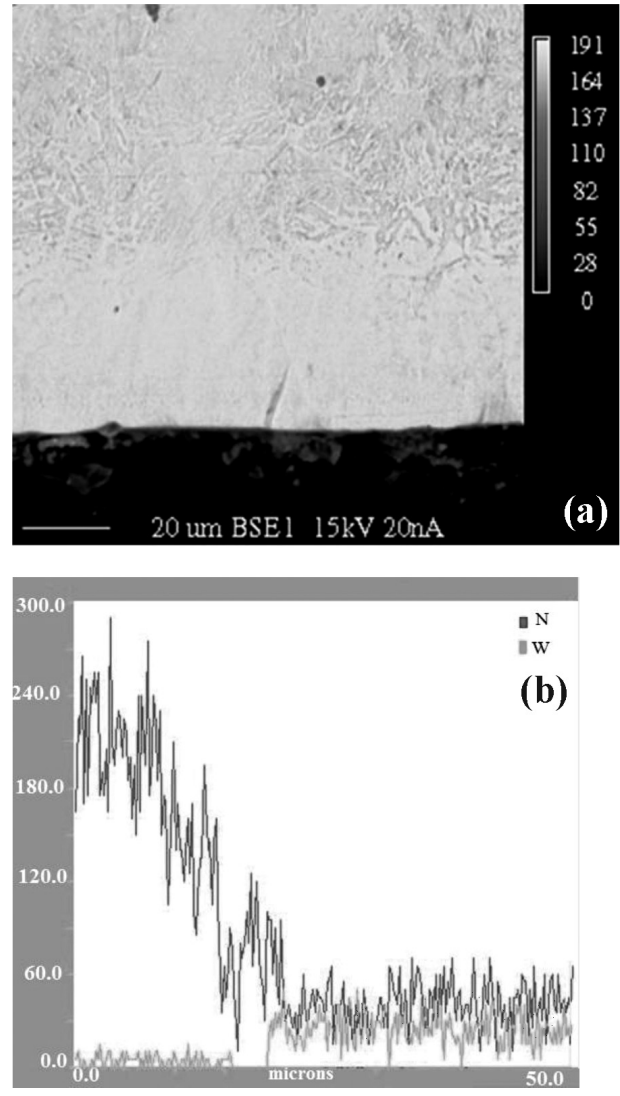

Figure 3: EPMA results for the modified layer of Sample 12 Slika 3: Rezultati EPMA spremenjene plasti vzorca 12

photographs. When the pulse number was increased, the thickness of the modified layer increased as due to the increased pulse number the process time and the amount of ionized gases were increased. ${ }^{6,7}$

Rapid heating and solidification induced a heavy plastic deformation, which caused a formation of dislocation cells due to one pulse bombardment. After the multi-pulse bombardments, both austenite and carbide types of the nanostructure particles were formed from the supersaturated solution.

The pulsed-plasma system affected the grain size of the modified layer. ${ }^{4}$ The grain structure of the outer surface of the modified layer was very fine and dense. The previous studies showed that the thermal stability, mechanical and tribological properties and the corrosion behavior of the materials are greatly influenced by the grain size. ${ }^{2,8,9}$

Figure 3 shows the EPMA results for the modified layer. The amounts of nitrogen and tungsten changed from the surface to the inner space. Firstly, the nitrogen was increased, then it was decreased and after that point the amount of tungsten was increased. These phases were very important for the surface properties. ${ }^{8}$

The XRD results for the sample groups are given in Figure 4. The figure clearly shows that the pulsedplasma treatment changed the diffraction profiles of the samples. The results of the X-ray analysis indicate that
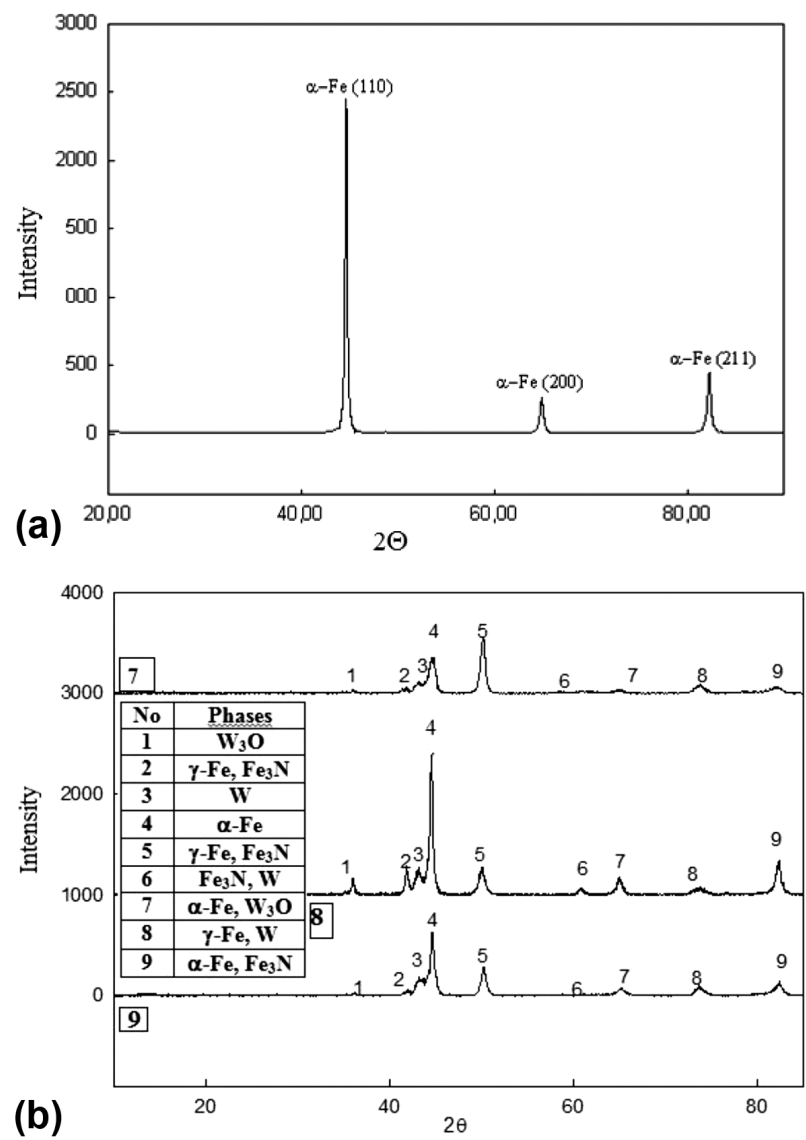

Figure 4: XRD analysis of: a) un-treated AISI 4140 steel, b) Sample 7, Sample 8 and Sample 9

Slika 4: Rentgenogram: a) neobdelano AISI 4140 jeklo, b) vzorec 7, vzorec 8 in vzorec 9

the new phases (such as $\gamma$-Fe, W and carbides) are formed on the steel surface after the plasma processing. Tungsten oxide was also determined from the analysis, due to the tungsten consumable electrode used during the pulsed-plasma treatment. ${ }^{10}$

While there was only the $\alpha$-Fe phase in the untreated AISI 4140 steel (Figure 4a), $\mathrm{Fe}_{3} \mathrm{~N}, \gamma$-Fe and tungsten were observed in the modified layer after the treatment (Figure 4b). As seen in Figure 4b, the pulse number is the only difference between the three specimens. The increased number of pulses leads to the growth of some existing phases, such as $\gamma^{\prime}-\mathrm{Fe}$, and the formation of new phases since the increasing pulse number also increases the pulsed-plasma-treatment time. This results in an increased amount of the ionized products doped into the surface. In addition, crystalline phases can be formed more easily with the increasing treatment time. .,7 $^{-1}$

Sample 7, having the highest pulse number, has the largest peak spacing (increased FWHM values). The increasing FWHM values of these phases cause a decrease in the grain size in accordance with the Scherer equation. ${ }^{8}$ Besides, a high cooling rate results in a small size of the precipitates, making them hard to be found with XRD. ${ }^{8,9}$ 


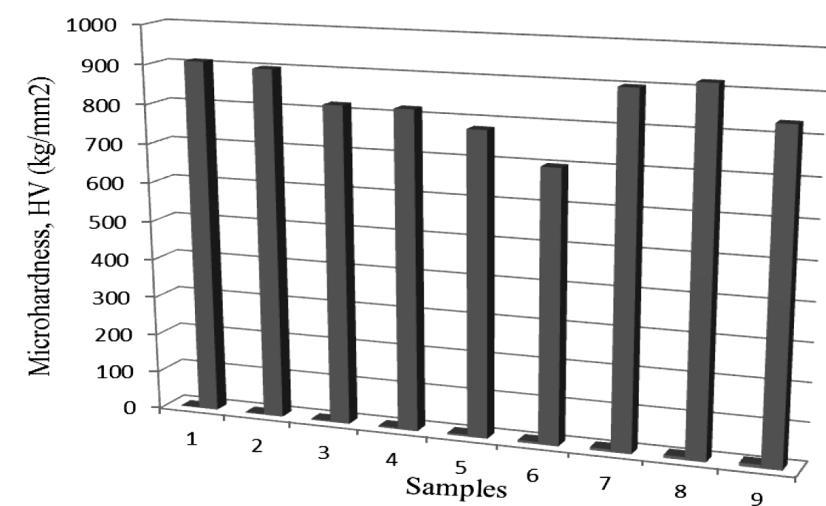

Figure 5: Microhardness values of the samples Slika 5: Mikrotrdota vzorcev

A comparison of the X-ray analysis results for the sample surfaces processed with different numbers of pulses showed a profound effect on the creation of new phases in the surface structure, hence, enhancing the surface properties. ${ }^{10,11}$

Figure 5 shows the results of the microhardness measurements for all the samples. The figure clearly illustrates that the pulsed-plasma treatment has a profound effect on increasing the microhardness values of the AISI 4140 steel, depending on the treatment parameters used. The new phases and the structure transformations improved the surface mechanical characteristics.

It was also found that there were some tungsten, nitride and austenite phases on the surfaces of the modified samples. The amount of these strong phases precipitated in the matrix phase was one of the reasons leading to an increase in the hardness values of the treated samples. ${ }^{4,12-14}$

Prior to the pulsed-plasma treatment, the initial hardness value of the specimens was recorded as $180 \mathrm{HV}$ and later its value was increased up to 700-950 HV. The hardness value measured for Sample 1 (15 pulses) was $910 \mathrm{HV}$; for Sample 2 (10 pulses) it was $900 \mathrm{HV}$ and for Sample 3 (5 pulses) it was $820 \mathrm{HV}$. The number of pulses affected the hardness values. An increase in the pulse number, or the intensity of the energy density absorbed by the surface, leads to the growth of the microhardness value. , $^{2,9}$

In the experiments, the maximum value of the surface microhardness was achieved for the samples treated with the maximum number of pulses. However, in these treatment regimes, a partial melting of the surface layer was observed, being due to the high temperatures caused by the frequently repeated pulses.

The structural defects, or disorder trappings, are easily formed at the high solidification rate induced by pulsed plasma, increasing the material hardness, known as the established point-defect strengthening models. ${ }^{13}$

Another reason for the increase in the hardness values of the samples was the decreased grain size due to

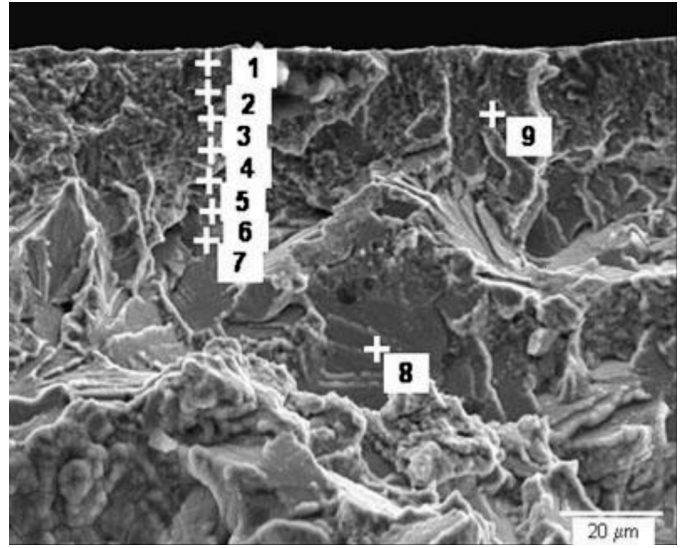

\begin{tabular}{|c|c|c|c|c|c|c|c|c|c|}
\hline No. & 1 & 2 & 3 & 4 & 5 & 6 & 7 & 8 & 9 \\
\hline $\begin{array}{c}\mathrm{W} \\
w / \%\end{array}$ & 2.610 & 3.200 & 1.198 & 2.067 & 1.154 & 1.190 & 2.091 & 1.889 & 1.190 \\
\hline
\end{tabular}

Figure 6: EDS analyses of the fracture surface of Sample 3

Slika 6: EDS-analize na površini preloma vzorca 3
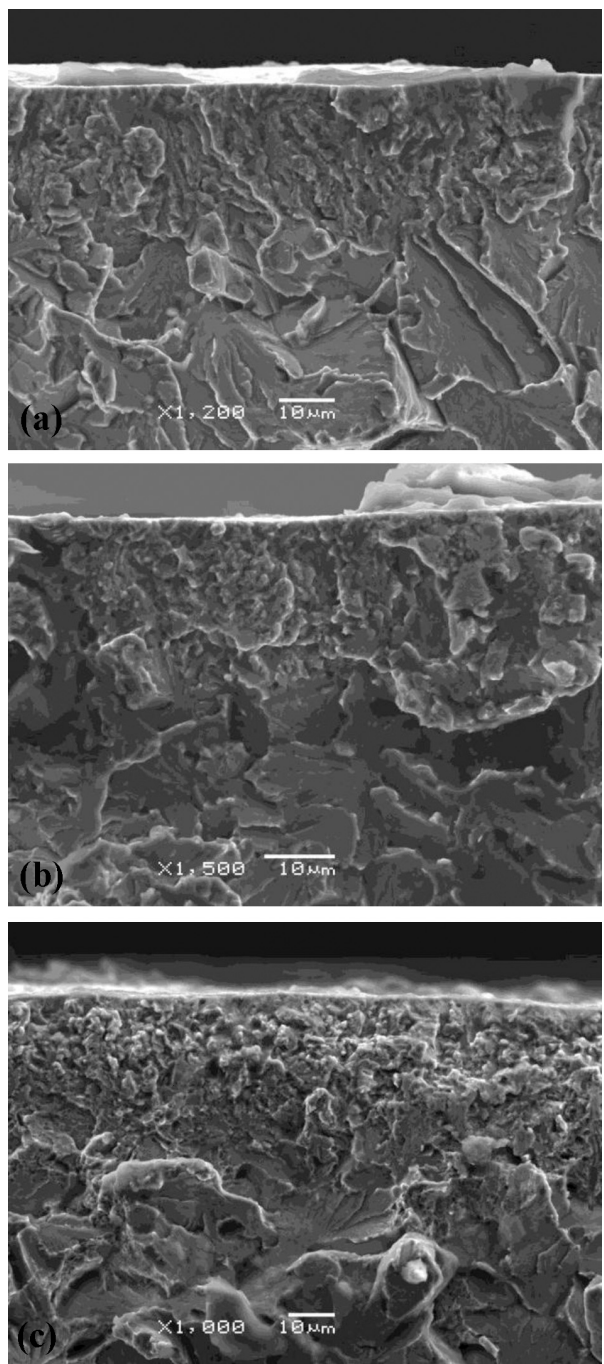

Figure 7: SEM micrographs of fracture surfaces: a) Sample 5, b) Sample 6, c) Sample 7

Slika 7: SEM-posnetki površine preloma: a) vzorec 5, b) vzorec 6, c) vzorec 7 
the increased cooling rate within the cycles of pulses. In the present experiment, the samples subjected to a high number of pulses during the pulsed-plasma treatment exhibit a low grain size and a high amount of the phase. ${ }^{11,13}$

The EDS analyses of the modified layer of Sample 3 are given in Figure 6. The modified layer and the resultant structure were easily detected and clearly seen in the fractured regions of the specimens. The EDS analysis was performed and the tungsten element was observed. In addition to this, the consumable-electrode tungsten amount in the matrix phase was calculated on the basis of the EDS analysis. Since there is no tungsten ingredient in the base metal, the existence of the tungsten from the electrode after the analysis indicates that the pulsed-plasma treatment was performed successfully.

The process parameters affect the structure and thickness of the modified layer (Figures 7a to 7c). From the SEM micrographs, it is observed that the fracture mechanism was brittle as characterized by the cleavage facets in the bulk material. ${ }^{10,11}$ Different fracture mechanisms occurred on the modified layer and the substrate. A fine-grained structure observed in the modified zone where a ductile fracture occurred is an indication of a hard structure. But ultra-fine intermetallic compounds were found in the matrix of this zone. ${ }^{4,14}$

\section{CONCLUSION}

In the light of the results of the experimental studies carried out on the surfaces of AISI 4140 steels modified with the pulsed-plasma technique, the findings given below were obtained:

1) The pulsed-plasma technique is used for a surface modification. Due to this technique, the thickness of a modified layer increases with the increasing pulse number, and the resultant structure becomes homogeneous.

2) In addition, a decrease in the grain size is observed as a result of fast heating and cooling of the modified layer. The grains outside of the modified zone are larger than the ones in the inside regions.

3) The phase and structure transformations occurred during the modification of the surfaces. The $\gamma-\mathrm{Fe}, \mathrm{Fe}_{3} \mathrm{~N}$ and $\mathrm{W}$ compounds were determined with the XRD studies.

4) The new phases and structure transformations improved the surface mechanical characteristics. The hardness values increased four times.

5) A ductile fracture occurred on the modified layer. A cleavage fracture was seen on the substrate.

\section{REFERENCES}

${ }^{1}$ K. M. Zhang, J. X. Zou, B. Bolle, T. Grosdidier, Vacuum, 87 (2013), 60-68, doi:10.1016/j.vacuum.2012.03.061

${ }^{2}$ N. Y. Tyurin, O. V. Kolisnichenko, N. G. Tsygankov, The Paton Welding Journal, (2004), 38-43

${ }^{3}$ C. Kwietniewski, W. Fontana, C. Moraes, A. S. Rocha, T. Hirsch, A. Reguly, Surface and Coatings Technology, 179 (2004) 1, 27-32, doi:10.1016/S0257-8972(03)00795-3

${ }^{4}$ Q. F. Guan, H. Zou, G. T. Zou, A. M. Wu, S. Z. Hao, J. X. Zou, Y. Qin, C. Dong, Q. Y. Zhang, Surface \& Coatings Technology, 196 (2005) 1-3, 145-149, doi:10.1016/j.surfcoat.2004.08.104

${ }^{5}$ J. L. Fan, T. Liu, H. C. Cheng, D. L. Wang, Journal of Materials Processing Technology, 208 (2008) 1-3, 463-469, doi:10.1016/ j.jmatprotec.2008.01.010

${ }^{6}$ Y. Y. Özbek, M. Durman, H. Akbulut, Tribology Transactions, 52 (2009) 2, 213-222, doi:10.1080/10402000802369721

${ }^{7}$ V. V. Uglov, V. M. Anishchik, N. N. Cherenda, Y. V. Sveshnikov, V. M. Astashynski, E. A. Kostyukevich, A. M. Kuzmitski, V. V. Askerko, Surface \& Coatings Technology, 202 (2008) 11, 2439-2442, doi:10.1016/j.surfcoat.2007.08.045

${ }^{8}$ Y. Yarali, M. Durman, H. Akbulut, Key Engineering Materials, 264-268 (2004), 561-564, doi:10.4028/www.scientific.net/KEM. 264-268.561

${ }^{9}$ Z. Zhou, J. Linke, G. Pintsuk, J. Du, S. Song, C. Ge, Journal of Nuclear Materials, 386-388 (2009), 733-735, doi:10.1016/j.jnucmat. 2008.12.306

${ }^{10}$ A. Buranawong, N. Witit-anun, S. Chaiyakun, A. Pokaipisit, P. Limsuwan, Thin Solid Films, 519 (2011) 15, 4963-4968, doi:10.1016/ j.tsf.2011.01.062

${ }^{11}$ Y. Hao, B. Gao, G. F. Tu, S. W. Li, C. Dong, Z. G. Zhang, Nuclear Instruments and Methods in Physics Research B, 269 (2011) 13, 1499-1505, doi:10.1016/j.nimb.2011.04.010

${ }^{12}$ Y. Y. Özbek, H. Akbulut, A. Ozel, M. Durman, Surface Modification of M2 Steel by Pulsed Plasma Technique, ICAMM, 2010, 46-50

${ }^{13}$ J. X. Zou, T. Grosdidier, K. M. Zhang, C. Dong, Applied Surface Science, 255 (2009) 9, 4758-4764, doi:10.1016/j.apsusc.2008.10.123

${ }^{14}$ X. Cheng, S. Hu, W. Song, X. Xiong, Applied Surface Science, 286 (2013), 334-343, doi:10.1016/j.apsusc.2013.09.083 